\title{
Mass spectroscopic and phytochemical screening of phenolic compounds in the leaf extract of Senna alata (L.) Roxb. (Fabales: Fabaceae)
}

\section{Solomon Oluwole Oladeji ${ }^{1 *}$, Funmilayo Enitan Adelowo ${ }^{1}$ and Kehinde Abraham Odelade²}

${ }^{1}$ Department of Pure and Applied Chemistry, Ladoke Akintola University of Technology, P.M.B 4000, Ogbomoso, Nigeria. Email: oladejioluwole@gmail.com. 2Department of Pure and Applied Biology, Ladoke Akintola University of Technology, P.M.B 4000, Ogbomoso, Nigeria.

\begin{abstract}
Senna alata (L.) Roxb. (Fabales: Fabaceae) is a medicinal plant basically used as antifungal and sometimes as antibacterial. Local people believe it is the amount of the plant consumed that constitutes to its potency, other believe it is the incantation thereby disregarding the bioactive components present in the leaf of $S$. alata. Therefore, there is a need to examine this claim by examining the bioactive components that are present in the plant. The methanolic and ethanolic extracts were obtained using soxhlet apparatus and the concentrated extracts were purified using column chromatography; the fractions were eluted and screened for their phytochemical and the mass spectroscopic analysis was performed using a mass spectrophotometer. The antimicrobial activity was carried out using agar disc diffusion method. The phytochemical analysis revealed the presence of important secondary metabolites such as anthraquinone, flavonoid and saponins while steroids was absent in the leaf extracts. The molecular ions of 250, 250, and 222 were obtained from the mass spectra. This showed the presence of methaqualone, cinnamic acid and isoquinoline. Ethanolic extracts showed a higher antimicrobial activity when compared with the methanolic extracts but less activity when compared with the standard used (amoxicillin). It could be concluded that the presence of these phytochemicals could be responsible for the observed antifungal and antibacterial activities on the susceptible organisms studied of the plant and also can be a natural source of antimicrobial substances of high importance.
\end{abstract}

Keywords: Therapeutics; Herbal medicine; Metabolite; Spectroscopy.

\section{Introduction}

Senna alata (L.) Roxb. is a medicinal plant of Fabaceae family. It has many common names such as Candle bush, Acapulo, Ringworm bush and Calabra
Received

May 31, 2016

Accepted

June 22, 2016

Released

June 30, 2016

Open Acess

Full Text Article

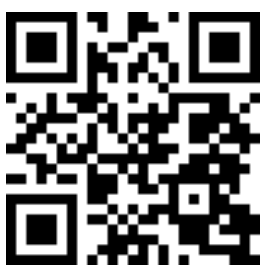

ORCIID

(ㄱ) 0000-0003-3355-2488

Solomon Oluwole Oladeji

() 0000-0002-1949-2418

Funmilayo Enitan

Adelowo

(ㄱ) 0000-0003-3380-7997

Kehinde Abraham

Odelade

bush. Wild senna (S. alata) is found in Ghana and Brazil, but it is now widely distributed in the United States of America and all over Africa, including Nigeria (Farnsworth and Bunyapraphatsara, 1992). 
The plant is very important in many areas of life. The applications are so numerous. The applications include for medicinal purposes, antimicrobial activities, antioxidant activities, its nutritional values and many others. Different parts and constituents of the plant are reported to exhibit several therapeutic properties, such as antibacterial, antifungal, antimicrobial and analgesic (Igoli et al., 2005; Makinde et al., 2007), antioxidants (Juvekar and Halade, 2006). The biological activity of plants is basically due to the presence of certain structural feature of a compound or its metabolite. One of these features is the effect of structural features like conjugated double bonds; this dictates UV absorption properties of some flavonoids or phenolic compounds. Alternatively, a certain activity may depend on the stereochemistry of the compound since target enzymes and biological systems in general are stereospecific. Therefore, it is inevitable to characterize the compounds present in plant materials.

Phenolic compounds are extracted and purified or clean up from the plant material before structural characterization of the compounds. First, the metabolic activity of the plant is halted by flash freezing and lyophilization or by extraction of the plant materials using solvent of high polarity such as methanol, ethanol and acetone. The samples were pulverized and subjected to pre-treatment before extraction in order to improve the extraction yield. The crude extract may be purified using cleanup methods such as adsorption, partition, gel permeation, ion exchange etc and also, column chromatographic methods such as gel filtration over Sephadex LH-20 and reversed-phase (RP) chromatography (Waterman and Mole, 1994; Wang et al., 1998). There are many physicochemical methods used for the identification of a specific compound. This is usually achieved by a combination of several physicochemical methods, such as ultraviolet spectroscopy (UV), gas chromatography-mass spectrometry (GCMS), circular-dichroism spectroscopy (CD), Thin-Layer Chromatography, optical rotation, Fourier Transform Infrared (FTIR)
Spectroscopy, nuclear magnetic resonance spectroscopy (NMR), Liquid Chromatography-Mass Spectrometry (LCMS), mass spectrometry (MS), and X-ray crystallography. If the compound of interest is already known, it can be identified with less measurement by comparing its characteristic features with literature values or the data of standard compounds.

The quantification of active compounds in medicinal plants have become very significant, it has been shown that in-vitro screening methods could provide the needed preliminary observations necessary to select crude plant extracts with potentially useful properties for further chemical and pharmacological investigations (De Fatima et al., 2006). The phenolic compound in S. alata varied from the leaf to the flower and this led to different approaches by the scientists to screen the plant for its therapeutic potency (Owoyale et al., 2005). In recent research carried out on $S$. alata plant, it was discovered that it contain hundreds of bioactive compounds (De Fatima et al., 2006). The compositions of these compounds are not the same and also, it was discovered that different bioactive compounds were present and this dictate its therapeutic functions.

Plants produce a large number of chemical substances or metabolites. In attempt to investigate these secondary metabolites, the extraction was done using soxhlet apparatus and also, identification and structural elucidation and the antimicrobial screening of the phytochemical present in the leaf of $S$. alata were investigated.

\section{Materials and methods}

\section{Solvents}

The solvents used for extraction and clean up (ethanol and n-hexane) were purified by distillation and the fraction collected at their boiling point.

\section{Collection of sample}

The leaves of S. alata were collected in a farm in Odokoto Area, Ogbomoso, Nigeria, between May and 
August, 2015, and identified by the herbarium unit of the Department of Pure and Applied Biology, LAUTECH, Ogbomoso. The leaves samples of S. alata were rinsed with distilled water and spread on a flat surface to air-dried for 25 days.

\section{Sample preparation}

The dried leaves samples were pulverized and sieved using a sieve of mesh size of $20 \mathrm{~mm}$. The sieved samples were stored in air-tight containers and stored at $4^{0} \mathrm{C}$ for further analysis.

\section{Extraction and concentration}

Soxhlet apparatus was used for the extraction and was carried out based on the method of Adelowo and Oladeji (2016) with little modification. The leaf extract was concentrated using rotary evaporator.

\section{Clean up}

The column used was made of Pyrex glass, and have small diameter so as to have effective separation and obtain distinctive bands. The cleanup method was carried out based on the method of Adelowo and Oladeji (2016). Ethanol and n-hexane (2:1 vol: $30 \mathrm{~mL}$ ) were used as the eluting solvent. The fractions were eluted and were collected in different beakers for subsequent analyses.

\section{Phytochemical screening of phenolic compound}

The phytochemical analysis of the leaf extracts were carried out for the presence of bio-molecular compounds such as anthraquinone, flavonoids, tannins, alkaloids and steroids using the standard qualitative procedure as described by Owoyale et al. (2005).

\section{Mass spectroscopic analysis of phenolic compounds}

The MS analysis of the fractions obtained from $S$. alata plant extracts was performed according to the method of Adelowo and Oladeji (2016).

\section{Antimicrobial screening}

Antibacterial screening. The antibacterial assay was carried out using nutrient agar (NA) as the media. Each NA plate contains different isolate. About $6 \mathrm{~mm}$ diameter filter paper discs were sterilized at $160{ }^{\circ} \mathrm{C}$ for $2 \mathrm{~h}$. Methanol and ethanol are used as control for methanolic and ethanolic extracts. The zone of inhibition of the bacterial spores was measured after incubating at $37^{\circ} \mathrm{C}$ for $24 \mathrm{~h}$. The minimum concentration of each extract that inhibits the growth of the bacterium was taken as the Minimum Inhibitory Concentration (M. I. C.).

Antifungal screening. The antifungal assay was carried out using potato dextrose agar (PDA) as the media. Each PDA plate contains different isolate. About $6 \mathrm{~mm}$ diameter filter paper discs were sterilized in Petri dishes at $160{ }^{\circ} \mathrm{C}$ for $2 \mathrm{~h}$. Methanol and ethanol are used as control for methanolic and ethanolic extracts. The zone of inhibition of the fungal spores was measured after incubating at $30{ }^{\circ} \mathrm{C}$ for 3 days. The minimum concentration of each extract that inhibits the growth of the fungus was taken as the Minimum Inhibitory Concentration (M. I. C.).

\section{Results and discussion}

\section{S. alata}

\section{The phytochemicals properties of}

The phytochemical analysis indicated the presence of important secondary metabolites (tannins, saponins, flavonoids, anthraquinone). The presence of bioactive components screened showed that $S$. alata plant posses antimicrobial properties. The result of phytochemical analysis showed that $S$. alata contained tannins, steroids, phenols and saponins (Table 1). Medicinal plants contain a wide variety of secondary metabolites or compounds such as tannins terpernoids, alkaloids, flavonoids; that dictates the 
Table 1. The phytochemicals properties of methanolic and ethanolic S. alata leaf (+ (present) and (absent)).

\begin{tabular}{lcc}
\hline Phytochemicals & Methanolic extract & Ethanolic extract \\
\hline Tannins & + & + \\
Saponins & + & + \\
Anthraquinone & + & + \\
Steroids & + & - \\
Flavonoids & + & + \\
\hline
\end{tabular}

therapeutic potency of the plants most especially the antimicrobial activities (Sule et al., 2010).

The therapeutic potentials of $S$. alata plant can be linked to the presence of these bioactive components. Similar phytochemical constituents such as flavonoids and tannins were also revealed to be active against pathogenic bacteria such as Bacillus cereus, Staphylococcus aureus amongst others (Kumar et al., 2012). The tannins present in the leaf of S. alata make it useful in production of antiseptic soap which are commonly used in bathing or cleansing of skin surfaces. Documented literatures have it that phytochemicals can be toxic to filamentous fungi, yeasts and bacteria (Treese and Evan, 2004), and also, inhibitory to viral reverse transcriptase (Onwuliri et al., 2004). A wide range of physiological activity of saponins, steroids, phenols and tannins are found to be more predominant and therefore may be responsible for the antimicrobial action (Sule et al., 2010). The leaf of the S. alata plant also showed the presence of Flavonoids, they are discovered to be a group of polyphenolic compounds that showed antifungal, antibacterial, anticancer and anticancer potency Ekpo et al. (2010).

Tannins have astringent properties which hasten the healing of wounds and inflamed mucous membrane due to their physiological activities such as antioxidant, antimicrobial and antiinflammatory properties. The use of $S$. alata leaves directly for healing fungal infections has long been in practice. Saponins have been traditionally used in detergents, pesticides and molluscides in addition to their industrial applications such as foaming and surface active agents. They help in controlling cardiovascular diseases and in controlling cholesterol in humans Onwuliri et al. (2004). In addition to their use in industry, saponins also have a wide range of medicinal applications (Sule et al., 2010).

Mass spectrometric analysis of phenolic compounds in S. alata leaf

The mass spectra of the phenolic compounds in $S$. alata leaf extracts were determined by conventional electron impact ionization. In the mass spectrum of each compound, the molecular ion, base peak and the fragmentation of the compound were shown.

\section{methaqualone \\ Mass spectrometric analysis of} Methaqualone (Figure 4) gave relatively weak molecular ions under electron impact conditions except the base peak which gave a relative density of $100 \%$. The observed fragment ions of methaqualone are shown in Table 2 with their respective $\mathrm{m} / \mathrm{z}$ values and their relative intensity. The possible fragmentation pattern of methaqualone is given in scheme 1 (Figure 3). The fragment showed $\mathrm{m} / \mathrm{z}$ values of $65,91,132$ and 235 . Also, the mass spectrum of methaqualone is given in Figure 2. In the spectrum of methaqualone, the $\mathrm{m} / \mathrm{z}$ value of 235 gave the highest relative intensity due to the loss of $\mathrm{CH}_{3}$. from the molecular ion of $\mathrm{m} / \mathrm{z}$ of 250. 


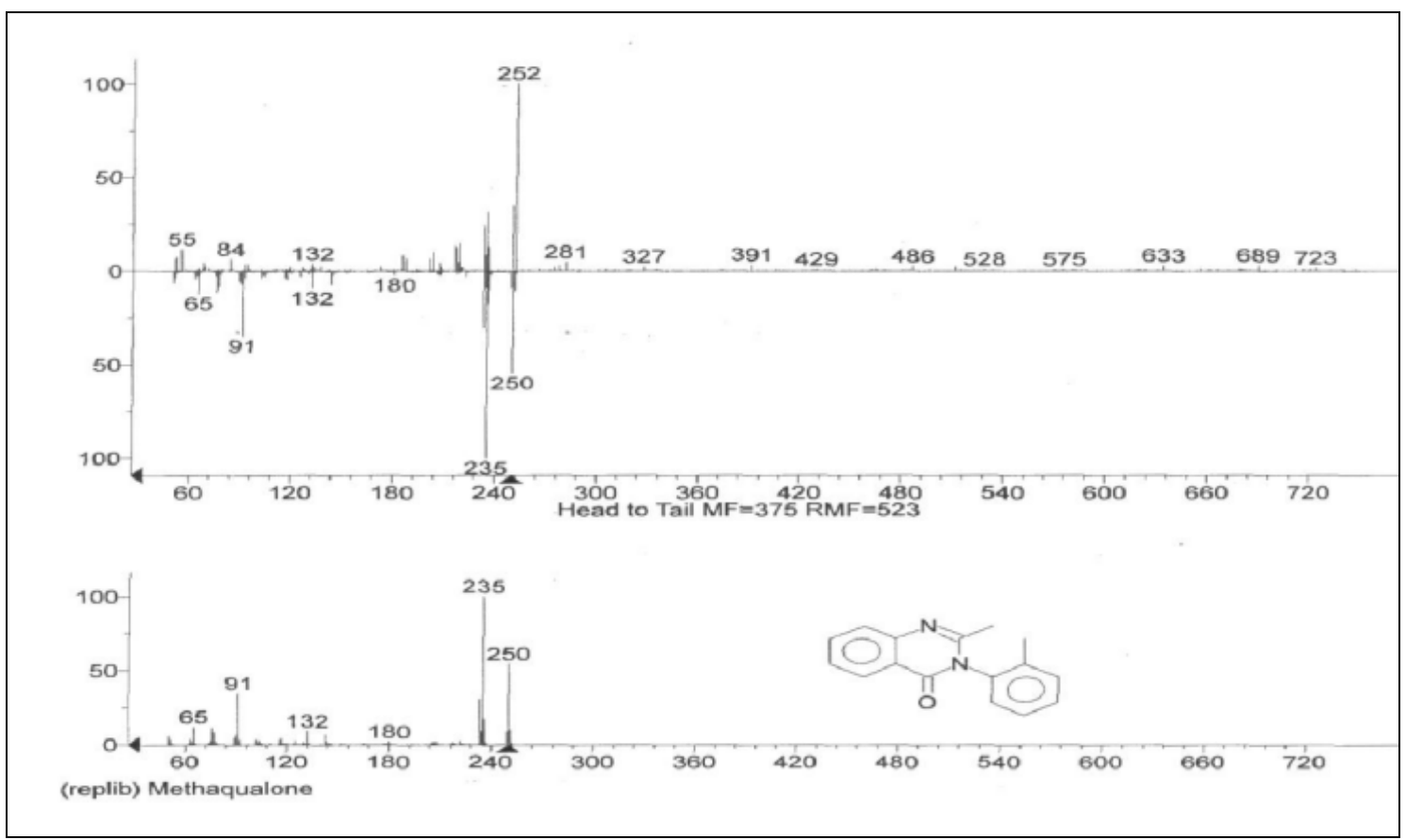

Figura 3. Mass spectrum of methaqualone.

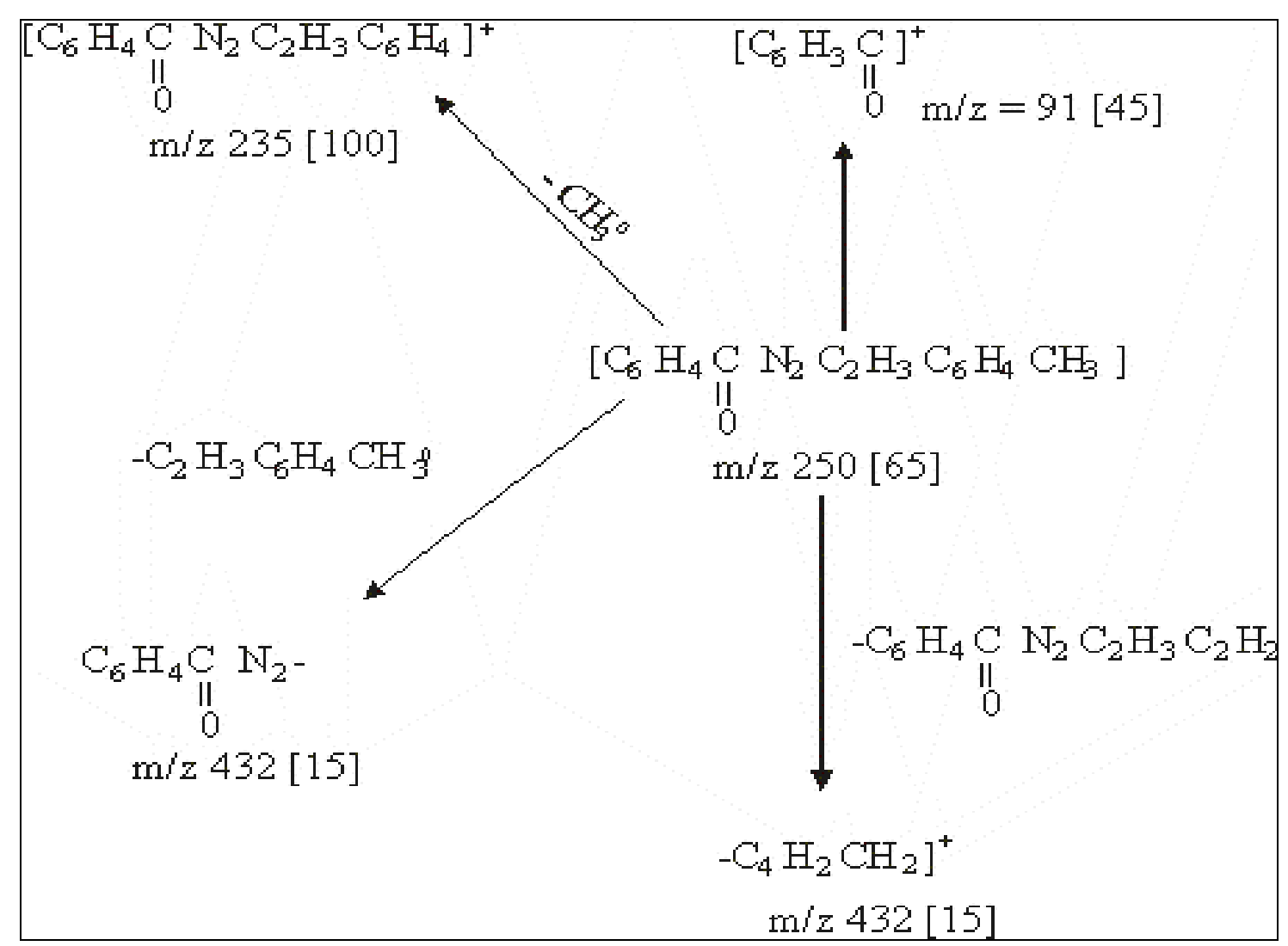

Figure 4. Fragmentation pattern of methaqualone (Scheme 1). 
Table 2. Principal ions in the electron impact mass spectrum of methaqualone $\mathrm{C}_{6} \mathrm{H}_{4} \mathrm{C}=\mathrm{ON}_{2} \mathrm{C}_{2} \mathrm{H}_{3} \mathrm{C}_{6} \mathrm{H}_{4} \mathrm{R}$ $\left[\mathrm{R}=\mathrm{CH}_{3}\right]$.

\begin{tabular}{lcc}
\hline Fragment ion(s) & m/z value(s) & Relative intensity \\
\hline$\left.-\mathrm{CH}_{3} \mathrm{H}_{2} \mathrm{CH}_{3}\right]^{+}$ & 65 & 15 \\
$\left.-\mathrm{C}_{6} \mathrm{H}_{3} \mathrm{C}=\mathrm{O}^{+}\right]^{+}$ & 91 & 45 \\
${ }^{+}\left[\mathrm{C}_{6} \mathrm{H}_{4} \mathrm{C}=\mathrm{ON}_{2} \mathrm{C}_{2} \mathrm{H}_{3} \mathrm{C}_{6} \mathrm{H}_{4}{ }^{-}\right.$ & 235 & 100 \\
${ }^{+}\left[\mathrm{C}_{6} \mathrm{H}_{4} \mathrm{C}=\mathrm{ON}_{2^{-}}\right.$ & 132 & 15 \\
\hline
\end{tabular}<smiles>Cc1ccccc1-n1c(C)nc2ccccc2c1=O</smiles>

Figure 2. Methaqualone structure.

\section{cinnamic acid \\ Mass spectrometric analysis of}

Cinnamic acid (Figure 5) gave a strong molecular ion under Electron Impact condition. Fragment ions were also observed at m/z 235, 203, 175, 115, 89, 73 and 59. The fragmentation pattern of this compound is represented in scheme 2 (Figure 6). A weak peak corresponding to the loss of $\left.-\mathrm{Si}\left(\mathrm{CH}_{3}\right)_{3} \mathrm{H}_{2}\right]^{\text {] from the }}$ molecular ion was observed in the spectrum, this lead to the $\mathrm{m} / \mathrm{z}$ value of 175 (Table 3). From the mass spectrum (Figure 7 ), the $\mathrm{m} / \mathrm{z}$ value for the cinnamic acid $[\mathrm{m} / \mathrm{z}$ 250] gave the base peak. The loss $\left.-\mathrm{CH}=\mathrm{CH}-\mathrm{C}_{6} \mathrm{H}_{4}-\mathrm{O}-\mathrm{Si}\left(\mathrm{CH}_{3}\right)_{3}\right]$ corresponding to the $\mathrm{m} / \mathrm{z} 177$ from the molecular ion. Also observed was a prominent peak due to the loss of the $\mathrm{CH}_{3}$ radical, which showed a relative intensity of $75 \%$.

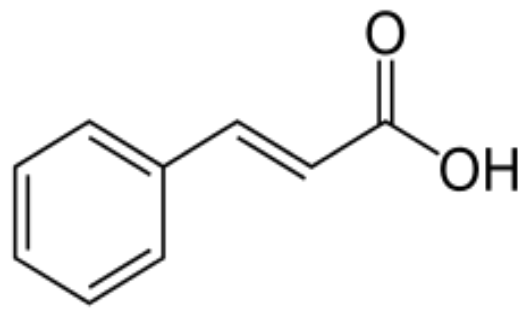

Figure 5. Cinnamic acid structure.

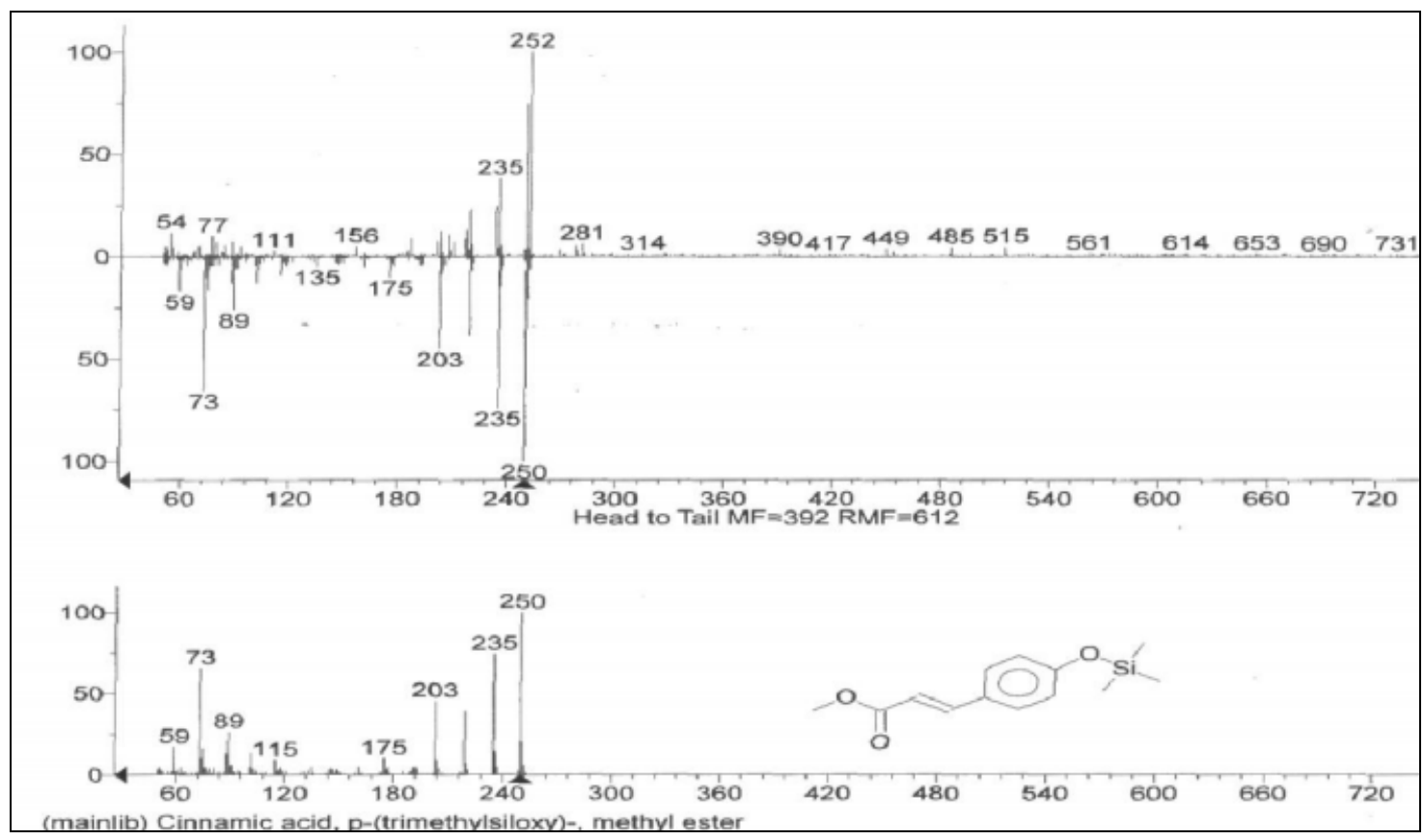

Figure 6. Mass spectrum of cinnamic acid. 


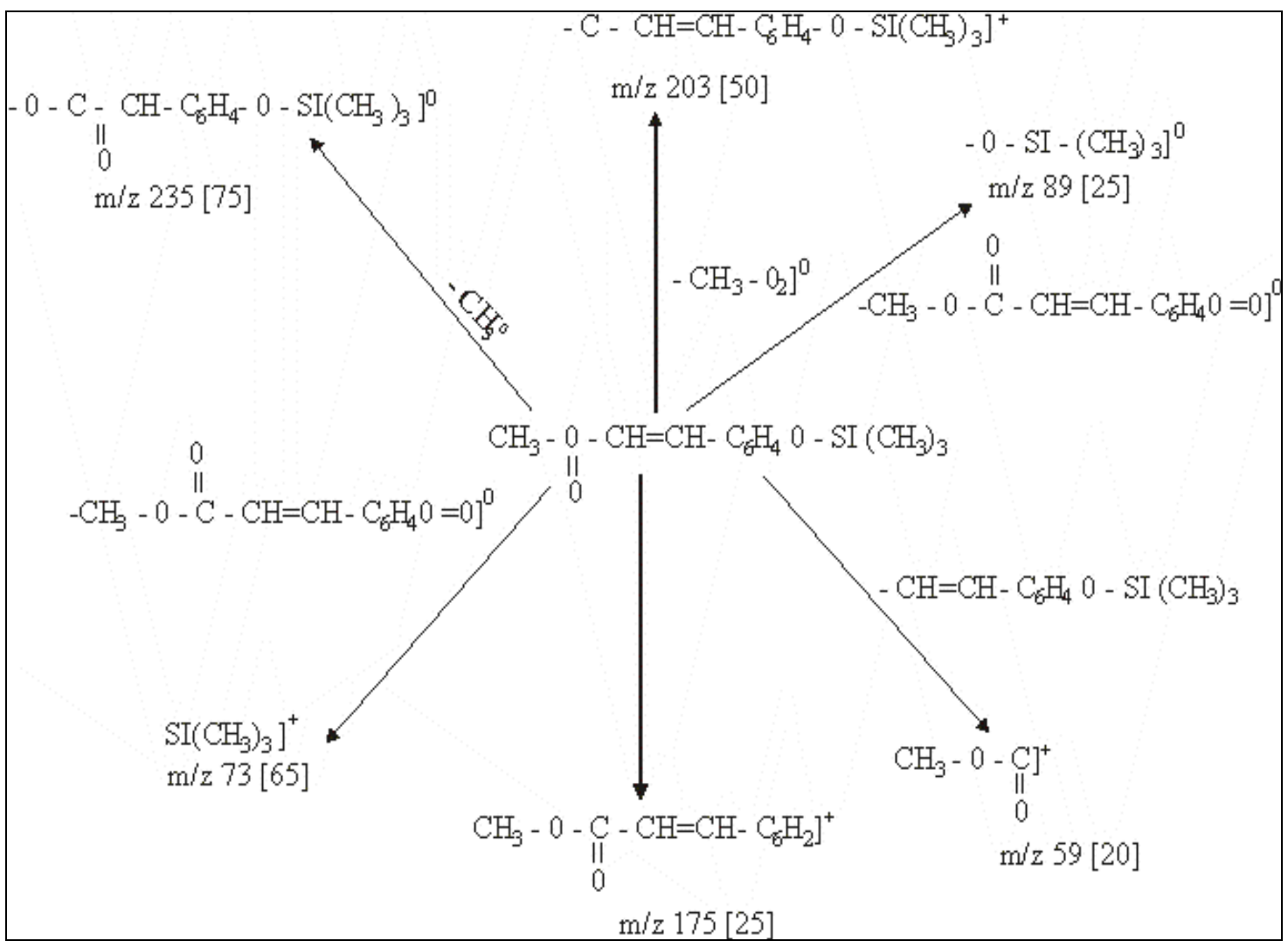

Figure 7. Fragmentation pattern of cinnamic acid (scheme 2).

Table 3. Principal ions in the Electron Impact mass spectrum of Cinnamic acid, $p$ - (trimethylsiloxy)-, methyl ester.

\begin{tabular}{lcc}
\hline Fragment Ion(s) & $\mathbf{m} / \mathbf{z}$ value (s) & Relative Intensity (\%) \\
\hline$\left.-\mathrm{CH}_{3}-\mathrm{O}-\mathrm{C}=\mathrm{O}\right]^{+}$ & 59 & 20 \\
$\left.-\mathrm{Si}\left(\mathrm{CH}_{3}\right)_{3}\right]^{+}$ & 73 & 65 \\
$\left.-\mathrm{O}-\mathrm{Si}\left(\mathrm{CH}_{3}\right)_{3}\right]^{+}$ & 89 & 25 \\
${ }^{+}\left[\mathrm{CH} \mathrm{CH}_{3}-\mathrm{O}-\mathrm{C}=\mathrm{O}-\mathrm{CH}=\mathrm{CH}-\mathrm{C}_{6} \mathrm{H}_{2^{-}}\right.$ & 175 & 15 \\
$\left.-\mathrm{C}-\mathrm{CH}=\mathrm{CH}-\mathrm{C}_{6} \mathrm{H}_{4}-\mathrm{O}-\mathrm{Si}-\left(\mathrm{CH}_{3}\right)_{3}\right]^{+}$ & 203 & 50 \\
$\left.-\mathrm{O}-\mathrm{C}=\mathrm{O}-\mathrm{CH}=\mathrm{CH}-\mathrm{C}_{6} \mathrm{H}_{4}-\mathrm{O}-\mathrm{Si}\left(\mathrm{CH}_{3}\right)_{3}\right]^{+}$ & 235 & 75 \\
\hline
\end{tabular}

\section{isoquinoline}

Mass spectrometric analysis of

Isoquinoline (Figure 10) gives the principal ions in the mass spectrum of Isoquinoline (Figure 8) were given in Table 4. For the entire fragments observed, the molecular ion observed was a weak peak. The molecular ion observed showed $\mathrm{m} / \mathrm{z}$ value of 222 with a low relative intensity. The base peak from the spectrum is observed with $\mathrm{m} / \mathrm{z}$ value of 162 . Prominent peaks of $\mathrm{m} / \mathrm{z}$ values of $252,190,162,118$ and 77 corresponding to the loss of some radicals from the molecular ion were observed. The fragmentation pattern of Isoquinoline is given in scheme 3 (Figure 9). The base peak from the spectrum (Figure 9) was obtained by the loss of $\left.-\mathrm{CH}_{2} \mathrm{C}_{6} \mathrm{H}_{3}-\mathrm{OH}-\mathrm{O}-\mathrm{CH}_{3}\right]$ (corresponding to $\mathrm{m} / \mathrm{z}$ value of 137 ) from the molecular ion. Also, the $\mathrm{m} / \mathrm{z} 118$ was obtained from the loss of $-\mathrm{C}_{2} \mathrm{H}_{5}-\mathrm{NH}-\mathrm{CH}_{2}-\mathrm{C}_{6} \mathrm{H}_{3} \mathrm{OH}-\mathrm{O}-\mathrm{CH}_{3}$ ] to give $25 \%$ relative intensity. 


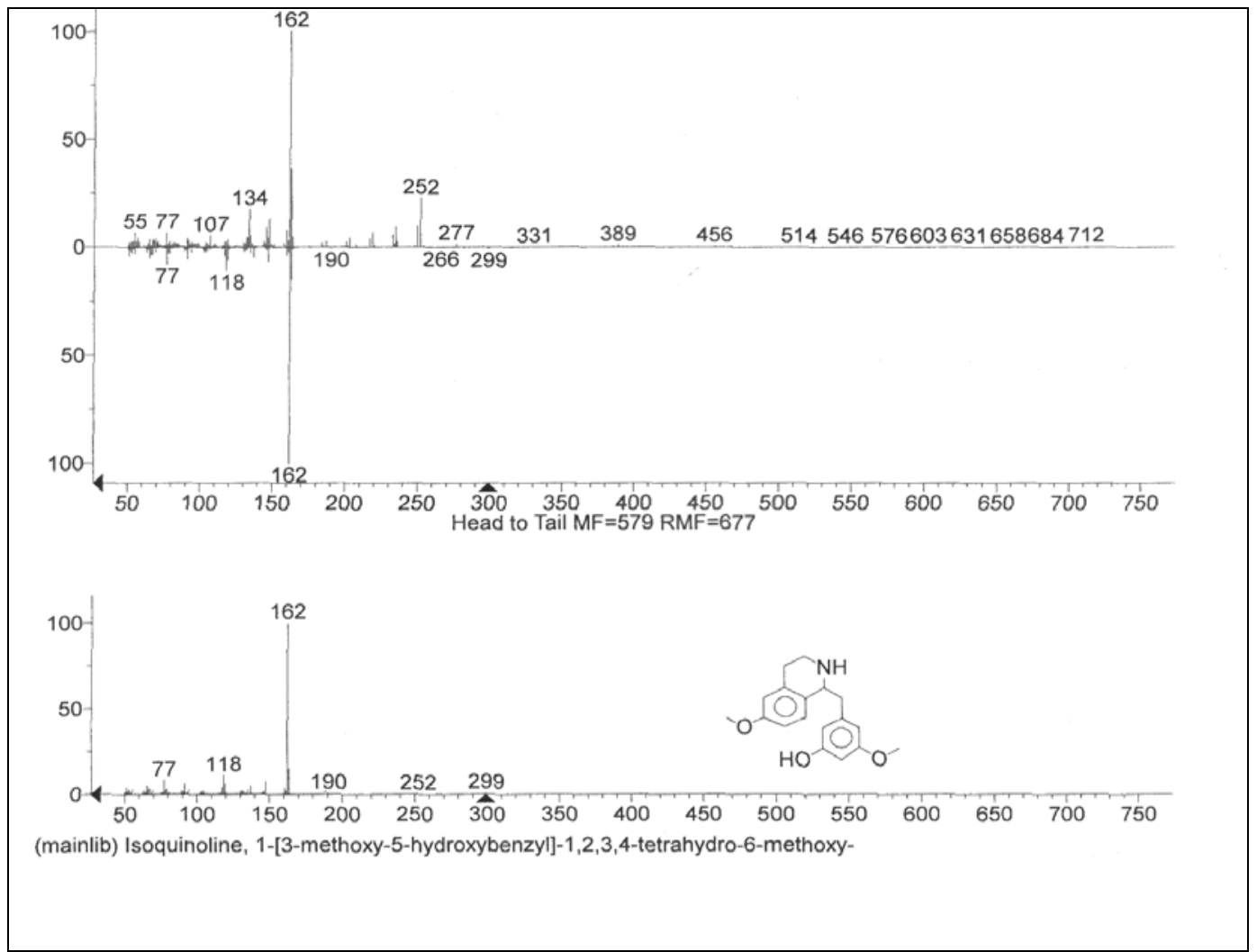

Figure 8. Mass spectrum of isoquinoline.

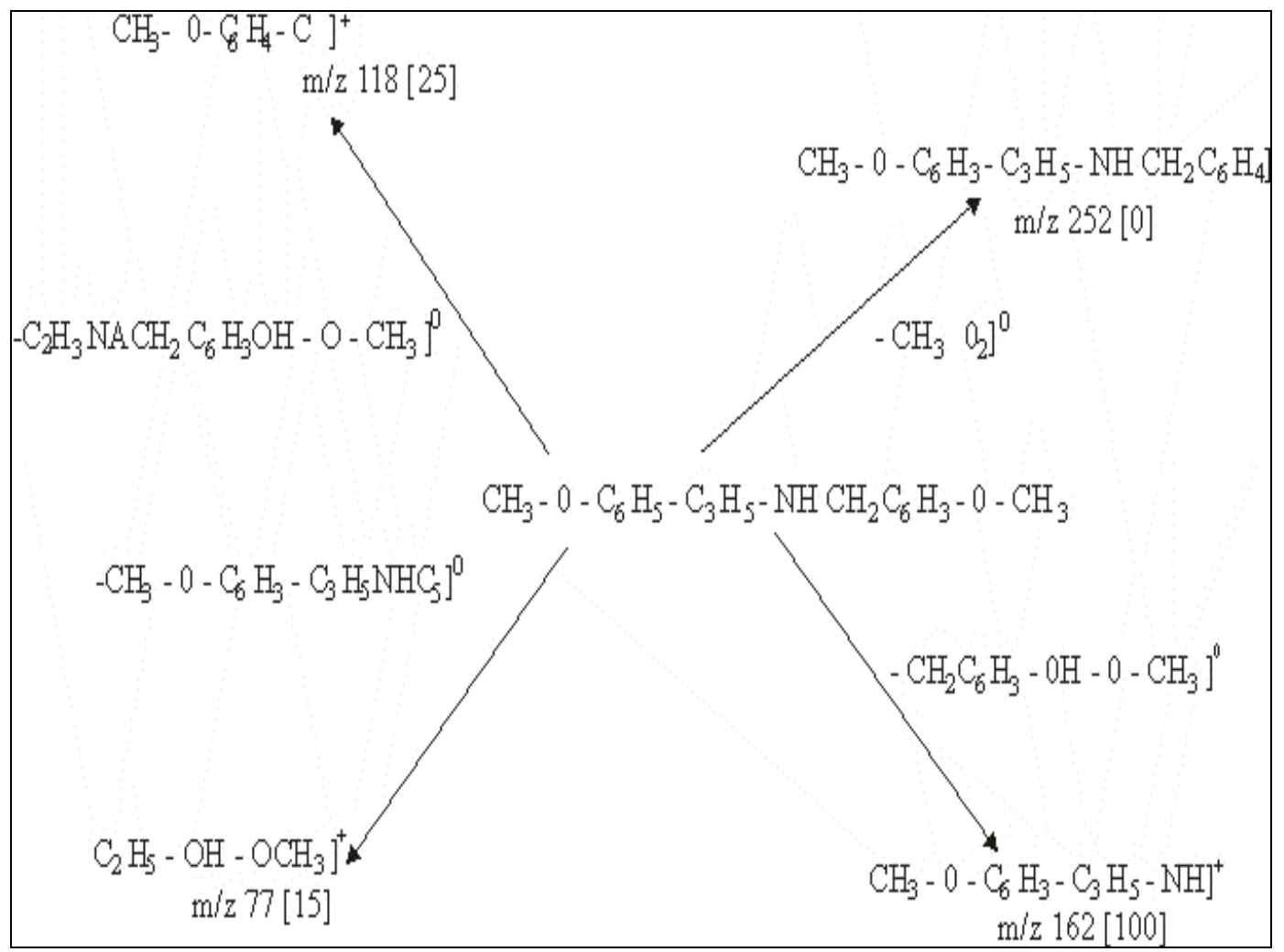

Figure 9. Fragmentation pattern of isoquinoline (Scheme 3). 
Table 4. Principal ions observed in the electron impact mass spectrum of isoquinoline.

\begin{tabular}{|l|c|c|}
\hline Fragment ion(s) & m/z value (s) & Relative Intensity (\%) \\
\hline$\left.-\mathrm{C}_{2} \mathrm{H}_{5}-\mathrm{OH}-\mathrm{OCH}_{3}\right]^{+}$ & 77 & 15 \\
\hline${ }^{+}\left[\mathrm{CH}_{3}-\mathrm{O}-\mathrm{C}_{6} \mathrm{H}_{3}-\mathrm{C}-\right.$ & 118 & 25 \\
\hline${ }^{+}\left[\mathrm{CH}_{3}-\mathrm{O}-\mathrm{C}_{6} \mathrm{H} 3-\mathrm{C}_{3} \mathrm{H}_{5}-\mathrm{NH}-\right.$ & 162 & 100 \\
\hline${ }^{+}\left[\mathrm{CH}_{3}-\mathrm{O}-\mathrm{C}_{6} \mathrm{H}_{3}-\mathrm{C}_{3} \mathrm{H}_{5}-\mathrm{NH}-\mathrm{CH}_{2}-\mathrm{C}_{6} \mathrm{H}_{4}-\right.$ & 252 & 0 \\
\hline
\end{tabular}

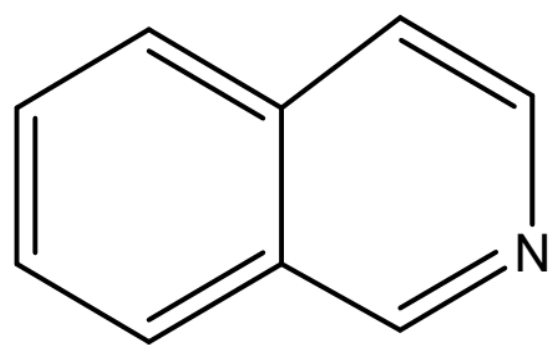

Figure 10. Isoquinoline structure.

\section{Antimicrobial activities of phenolic compounds in $S$. alata leaf extracts}

The growth of fungi and bacteria is a measure of fungitoxicity and bacteriotoxicity of the fungicide and bactericide respectively. The minimum concentration (MIC) obtained from the activities of the test organisms against the fraction and amoxicillin are given in Table 5.

The ethanolic and methanolic of $S$. alata plant showed antibacterial and antifungal properties and all tested bacterial and fungal isolates responded positively to the extracts. The minimum inhibitory concentrations are shown in Table 5.There are tremendous microbial effects on Aspergillus niger and Candida albican compared to the corresponding bacteria used. This agrees well with several reports in which similar observations were made
(Khan et al., 2001; Abubacker et al., 2008). The result of this study revealed the effect of ethanol fractions on Candida albicans to be significantly higher than the methanol leaf which thus similar to report of Ogunti and Olujoba, (1993) where the ethanolic fraction was found to exhibit marked antimicrobial activity against Aspergillus niger and Candida albicans when compared to methanolic fractions. The extracts showed potency when compared with the standard antibiotics used (Amoxicillin). The presence of these phenolic compounds has been found to be responsible for the fungicidal activity (Khan et al., 2001). Variations in the concentrations of the phenolic compounds in ethanolic and methanolic fractions are responsible for the differences in the fungicidal activity between the methanolic and ethanolic (Timothy et al., 2012). The Minimum Inhibitory Concentration obtained showed that Aspergillus niger and Candida albicans are more susceptible to the ethanolic leaf even at low concentration when compared with Staphylococcus aureus, Bacillus cereus and Klebsiella spp. This study justifies the ethno medical use of this plant in the inhibition of bacterial and other fungal diseases. We believe that the results obtained from this study are an encouragement for further studies that will lead to the elucidation of the structure of the active components.

Table 5. Inhibitory effect of the fractions on the growth of fungi and bacteria species expressed through MIC in $\mu \mathrm{g} / \mathrm{mL}$.

\begin{tabular}{lccc}
\hline Test organisms/ fractions & ME leaf & EE leaf & Amoxicillin \\
\hline Staphylococcus aureus & 19 & 21 & 25 \\
Bacillus cereus & 16 & 20 & 25 \\
Klebsiella spp & 18 & 22 & 24 \\
Aspergillus niger & 24 & 29 & 30 \\
Candida albican & 25 & 28 & 29 \\
\hline
\end{tabular}

Where: ME= Methanolic, EE= Ethanolic (units are in millimeters). 


\section{Conclusion}

In this study, the mass spectroscopic and phytochemical analysis of S. alata was investigated. The analyses showed that the plant contains saponins, reducing sugars, flavonoids, methaqualone, cinnamic acid, toluidine, terpenes, isoquinoline, anthraquinone and glycosides which could be responsible for the therapeutic potency of the plant. The highest concentration of phenolic compounds in the extracts was obtained using solvents of high polarity; the methanolic extract manifested greater power of extraction for phenolic compounds from S. alata. The results of the study suggested the great value of the species $S$. alata for use in pharmacy and phytotherapy; therefore, it could serve as a natural source of antimicrobial substances of high importance.

\section{Acknowledgements}

The authors want to appreciate the efforts of Doctor Olugbenga Bello of the Department of Pure and Applied Chemistry, LAUTECH, Ogbomoso, Nigeria, for his contributions during the course of the study.

\section{Conflict of Interest}

Authors declare that they have no conflict of interests.

\section{References}

Abubacker, M.; Ramanathan, R.; Senthil, K.T. In vitro antifungal activities of Cassia alata Linn. flower extract. Natural Product Rad., v. 7, p. 6-9, 2008.

Adelowo, F. E.; Oladeji, S. O. Spectrophotometric analysis of phenolic compounds in Senna alata. Am. J. Adv. Sci. Res., v. 3, p. 246-253, 2016.

Ekpo, M. A.; Etim, P. C. Antimicrobial activity of ethanolic and aqueous extracts of Sida acuta on microorganisms from skin infections. Journal of Medical Plant Research, v. 3, p. 621-624, 2010.
Farnsworth, N. R.; Bunyapraphatsara, N. Thai Medicinal Plant: recommended for Primary Health Care System. Bangkok, Thailand: Prachachon Company, 1992.

Igoli, J.; Ogaji, O.; Igoli, N. Tor-Anyiin T. A. Traditional medicinal practices among the Igede people of Nigeria (part II). African Journal of Traditional Complementary and Alternative Medicine, v. 2, p. 134-152, 2005.

Juvekar, R.; Halade, G. V. Hypoglycemic activity of Cassia auriculata in neonatal streptozotocin-induced non-insulin dependent diabetes mellitus in rats. Journal of Natural Remedy, v. 6, no. 1, p. 14-8, 2006.

Khan, M.; Kihara, M.; Omoloso, A. Antimicrobial activity of Cassia alata. Fitoterapia, v. 72, p. 561-564, 2001.

Kumar, A.; Shukla, R.; Singh, P.; Prasad, C. S.; Dubey, N. K. Assessment of Thymus vulgaris L. essential oil as a safe botanical preservative against post harvest fungal infestation of food commodities. Innovation Food Sci. Emerg., $\begin{array}{lll}\text { v. 9, } & \text { no. 4, } 575-580, & 1984 .\end{array}$ http://dx.doi.org/10.1016/j.ifset.2007.12.005

Makinde, A.; Igoli, J.; Amal, L.; Shaibu, S.; Garbal, A. Antimicrobial activity of Cassia alata. African Journal of Biotechnology, v. 6, p. 1509-1510, 2007.

Ogunti, E.; Olujoba, A. Laxative activity of Cassia alata. Fitoterapia. Economical Botany, v. 64, p. 437-439, 1993.

Onwuliri, F. C. Antimicrobial studies of the extracts of Acalypha wllkesiana L. on microorganisms associated with wound and skin infections. West Africa Journal of Biological Science, v. 15, p. 15-19, 2004.

Owoyale, J.; Olatunji, G.; Oguntoye, S. Antifungal and antibacterial activities of an ethanolic extract of Senna alata leaves. Journal of Applied Science and Environmental Management, v. 9, p. 105-107, 2005.

Owoyale, J. A.; Olatunji, G. A.; Oguntoye, S. O. Antifungal and antibacterial activities of an alcoholic extract of Senna alata leaves. Journal of Applied Science and Environmental Management, v. 9, no. 3, p. 105-107, 2005. Available from: $<$ http://unilorin.edu.ng/ publications/olatunji/Prof. Olatunji 11.pdf $>$. Accessed in: May 6, 2016.

Sule, W.; Okonko, I.; Joseph, T.; Ojezele, M.; Nwanze, J.; Alli, J.; Adewale, O.; Ojezele, O. In-vitro antifungal activity of Senna alata Linn. 
crude leaf extract. Advanced Applied Scientific Research, v. 1, p. 14-26, 2010.

Timothy, S.; Lamu, F.; Rhoda, A.; Adati, R.; Maspalma, I.; Askira, M. Acute toxicity, phytochemistry and antibacterial activity of aqueous and ethanolic leaf extracts of Cassia alata Linn. International Research Journal of Pharmacy, v. 3, p. 73-76, 2012.

Trease, E.; Evans, W. C. Pharmacognosy. 15th ed. London: Saunders Publisher, 2004.

Wang, L.; Kim, D.; Lee, C. Effects of heat processing and storage on flavanols and sensory qualities of green tea beverage. Journal of Agricultural Food Chemistry, v. 48, p. 42274232, 2000.

Waterman, P. G.; Mole, S. Analysis of phenolic plant metabolites. Oxford: Blackwell Scientific Publications, 1994.

License information: This is an open-access article distributed under the terms of the Creative Commons Attribution License, which permits unrestricted use, distribution, and reproduction in any medium, provided the original work is properly cited. 